\title{
Legal Review of the Implementation of the COVID-19 Task Force Circular on Virtual Mudik Activities during the Pandemic
}

\author{
Yadhy Cahyady $^{1}$, Faisal Santiago ${ }^{2}$ \\ \{cahyavi@gmail.com ${ }^{1}$, faisalsantiago@borobudur.ac.id²\} \\ Universitas Borobudur, Jakarta, Indonesia ${ }^{1,2}$
}

\begin{abstract}
This study aimed to analyze the implementation of the COVID-19 Task Force Circular on virtual mudik activities during the pandemic. This study used a normative legal research method through a statutory approach. The research specifications used were descriptive analysis using secondary data obtained through literature review. The COVID-19 Task Force published Circular Letter Number 13 of 2021 on April 7, 2021 in order to carry out its tasks and avoid a rise in COVID-19 transmission during in the holiest seasons of Ramadan and Eid - ul in 1442 Hijri. The COVID-19 Task Force has issued a circular suspending Eid - ul mudik activities for year 1442 Hijri in all areas of Indonesia from 6 to 17 May 2021. Other than that, the whole community was encouraged to eat suhoor and break the fast with family at home, conduct virtual gatherings, and limit physical gatherings with family members or other relatives who are not in the same location. With this circular, the mudik activity, which has become a tradition for Indonesian people to celebrate Eid al-Fitr with family in their hometown, was suspended and encouraged to do it virtually. In this virtual mudik activity, factors such as (1) law, (2) law enforcement officers, (3) facilities, (4) community, and (5) culture affected the implementation of the circular.
\end{abstract}

Keywords: Virtual Mudik Activities; Task Force Circular; Pandemic

\section{Introduction}

In addition to facilitating the treatment of Corona Virus Disease 2019, Presidential Decree Number 82 of 2020 about the Committee for Handling Corona Virus Disease 2019 and National Economic Recovery, as revised by Presidential Regulation Number 108, was issued, as well as the recovery and transformation of the national economy. The Commission for the Settlement of COVID-19 and the Economic Policy Reconstruction was established by the president in 2020. The president was in charge of the committee, which included the following members (a) chairman; (b) vice chairman; (c) implementation team; (d) COVID-19 Handling Task Force; (e) National Economic Recovery Task Force; and (f) secretary. The COVID-19 Task Force as part of the committee has the following duties: 
a. Conducting and controlling the implementation of strategic policies related to the handling of COVID-19;

b. Resolving problems in the implementation of strategic policies related to the handling of COVID-19 quickly and accurately;

c. Supervising the implementation of strategic policies related to the handling of COVID-19;

d. Carrying out control of the Regional COVID-19 Handling Task Force; and

e. Establishing and implementing policies and other necessary steps in the context of accelerating the handling of COVID-19.

In carrying out its duties, the COVID-19 Task Force:

a. Has the authority to make decisions that are binding on ministries/agencies, regional governments, and other government agencies and

b. Communicates and coordinates with relevant ministries/agencies and local governments.

On April 7, 2021, in an effort to restrict the spread of COVID-19 during the ramadhan of 1442 Hijri, the COVID-19 Response Team published Circular Letter Number 13 of 2021 about the Reduction of Return for Eid - ul in 1442 Hijri and Attempts to Control the Growth of Corona Virus Disease 2019. (COVID-19). The issuance was justified because the community's movement was expected to increase during the ramadhan and Eid - ul in 1442 Hijri for religious, family, and tourism events, potentially increasing the rate of COVID-19 transmission.

During the holy month of Ramadan and Eid Al-Fitr in 1442 Hijri, the circular was issued with the goal of managing community movement limitations and maximizing the operation of the COVID-19 Command Post in Villages/Ward. The purpose of the circular was to monitor, manage, and assess COVID-19 transmission during Ramadan and Eid Al-Fitr in 1442 Hijri in order to prevent an increase in COVID-19 transmission. The COVID-19 Task Force ruled that the suspension period for Eid al-Fitr year 1442 Hijri was May 6-17 2021, and the control period was throughout the holy month of Ramadan and Eid Al-Fitr 1442 Hijri, through the circular. The scope stipulated in the circular included: (a) Public health protocols; (b) Controlling worship activities during the holy month of ramadan and eid prayer activities in 1 syawal 1442 hijri; (c) The suspension of mudik was in 6-17 may 2021 for all regions of indonesia; and (d) Optimizing the function of the village/ward covid-19 command post for the prevention and control of the spread of covid-19 during the holy month of ramadan and eid alfitr in 1442 hijri.

Regarding the suspension of mudik activities as well as the COVID-19 prevention and control, the circular regulated the following:

a. Temporary mudik suspension policy for communities using land, sea, and air across cities/districts/provinces/countries as an effort to control mobility during the holy month of Ramadan and Eid Al-Fitr in 1442 Hijri and

b. All community was encouraged to eat suhoor and break the fast with family at home, conduct virtual gatherings, and limit physical gatherings with family members or other relatives who were not in the same location.

Therefore, the mudik activity, which has become a tradition carried out by the Indonesian people ahead of Eid al-Fitr, was suspended and encouraged to be done virtually. Based on the aforementioned description, the research questions are as follows:

a. How was the implementation of the COVID-19 Task Force Circular Number 13 of 2021 for virtual mudik activities during the pandemic?

b. What were the factors that influence the implementation of the COVID-19 Task Force Circular Number 13 of 2021 on virtual mudik activities during the pandemic? 


\section{Methodology}

This study applied a normative legal research method through a statutory approach. The research specification was in the form of an analysis description so as to be able to provide a detailed, systematic, and comprehensive description of the implementation of the COVID-19 Task Force Circular Number 13 of 2021 on virtual mudik activities during the pandemic. Secondary data was gathered through a literature research in the form of primary and secondary legal texts. Deductive reasoning was used to assess and organize the data that had been acquired.

\section{Results and Discussion}

According to the Great Indonesian Dictionary, mudik means 1) to the village (upstream, inland) and 2) returning to one's hometown. The activity of returning to one's hometown during the ramadan period and Eid - ul in 1442 Hijri is defined by mudik, according to the circular of the COVID-19 Response Team Number 13 of 2021. From year to year, mudik has never been a worrying thing other than traffic jams. However, in 2020, mudik is a very worrying thing because of the COVID-19 pandemic hit Indonesia. Based on the results of a survey conducted online on March 28-April 2, 2020, the COVID-19 outbreak was not an obstacle for residents who intended to travel home. Although many of them chose to postpone, the percentage of residents who planned to travel home was quite large, which was around $44 \%$ of the total number of respondents, 4,602 . In fact, $60.64 \%$ of respondents who planned to travel home chose to carry out mudik on D-3 until the D-Day of Eid al-Fitr [1].

Mudik became very worrying because it would create other potential dangers as travelers were not $100 \%$ free of viruses. Travelers had the potential to become carriers of the virus from areas that had been exposed to COVID-19 so that they can become a source of transmission and expand the area of exposure to COVID-19. The potential for the virus to infect more people was getting bigger so that the epicenter of COVID-19 could appear due to the high flow of mudik activities to an area. This was evidenced by the fact that East Java and Central Java as areas that were estimated to be the largest recipients of travelers had become new epicenters for the spread of COVID-19 and occupied the top 5 regions with the highest number of positive cases in Indonesia [2]. The government had evaluated the Implementation of Restrictions on Community Activities (PPKM) and the policy of suspending mudik as well as tightening travel after the Eid holiday. The evaluation revealed that [3]:

a. when compared to the peak of cases on February 5, 2021, which was 176,672 cases, the number decreased as of May 26, 2021, 96,187 cases, showing a decrease of 45.5\%;

b. from data as of May 26, 2021, 55.6\% of active cases were on Java and $22.9 \%$ on Sumatra. The five provinces that contributed the most to $65 \%$ of national active cases were West Java (29,045 cases), DKI Jakarta (10,800 cases), Papua (8,799 cases), Central Java (8,429 cases), and Riau (5,244 cases). There were 3,038 active cases in West Sumatra and other provinces were below 3,000 cases;

c. on April 22, 2021 to May 14, 2021 (before and during the Eid holidays), there were 3.9 million people using public transportation (land, sea, and air). Meanwhile, in the period of May 15-24 (post-Eid holidays), only 2.5 million passengers were able to travel by public transportation; and 
d. in general, the policy of Eliminating Homecoming and Tightening Travel Requirements for Eid Al-Fitr in 2021 went quite well and succeeded in reducing community mobility in all modes of transportation. The implementation of the return flow after the 2021 Eid holiday also went smoothly and under control.

Based on the evaluation period from April 22, 2021 to May 14, 2021 (before and during Eid holidays), it was recorded that 3.9 million people used public transportation (land, sea, and air). It can be concluded that the government's appeal for all people to carry out virtual mudik during the period of suspending mudik from 6-17 May 2021 for all parts of Indonesia was not fully complied with by the community. This was influenced by many factors. Furthermore, this study analyzed the factors that influence the implementation of the COVID-19 Task Force Circular Number 13 of 2021 on virtual mudik activities during the pandemic by paying attention to the factors that affect law enforcement.

The main problem of law enforcement actually lied in the pull factors. These factors have a neutral meaning so that the positive or negative impact lies in the content of these factors. These factors that affected law enforcement were as follows [4] (a) the legal factors; (b) law enforcement officers factors, namely the parties that formed and applied the law; (c) facilities and infrastructures that supported law enforcement; (d) community factors, namely the environment in which the law applied; and (e) cultural factors in social life. The analysis of these factors is described as follows:

\section{a) Legal Factors}

What is meant by law in this study is law in the material sense in the form of policies set by the COVID-19 Task Force in the form of Circular Letter Number 13 of 2021. The circular letters were not categorized as laws and regulations as referred to in the Act Number 12 of 2011 concerning the Establishment of Legislation as amended by Law Number 15 of 2019. The concept of discretion, also known as freies ermessen, is one of the formal forms of policy rules issued from the power of state administration authorities. The concept of discretion, also known as freies ermessen, is the foundation for state administration officials' policymaking authority. Policy rules are a formal type of policy established by state administration authorities based on the discretionary concept [5].

As per Central Administration Legal No. 30 of 2014, delegation of authority is a judgment and/or action taken andor conducted by a government official to address concrete issues in state bureaucracy, such as laws and regulations that provide options, do not regulate, are incomplete or unclear, and/or government stagnation. Every government official discretion strives to (1) expedite the administration of government; (2) fill legal voids; (3) provide legal certainty; and (4) overcome the stagnation of government in certain circumstances for the benefit and public interest. Policy regulations only function as part of the operational implementation of government tasks so that they cannot change or violate from statutory regulations. This regulation is a kind of spigelsrecht from the laws or regulations. Therefore, this regulation is also known as psudo-wetgeving (pseudolaw) [6].

In practice, it is not uncommon to find products of policy regulations (beleidregel) that have different characteristics from statutory regulations. Policy regulations cannot be separated from the terminology of freies ermessen in which the state administrative officials or institutions formulate a policy in the form of juridische regels such as guidelines, announcements, circulars, and announcing the policy [7]. The Minister for State Apparatus Empowerment and Bureaucratic Reform issued Regulation No. 80 of 2012 about Guidelines for Government Agency Service Scripts. it is regulated that regulatory official texts consist of 
regulations, guidelines, implementation instructions, Standard Operating Procedures (SOP), and circulars. What is meant by a circular letter is an official document that contains notifications about vital or urgent things.

Strategy rule, per the Bagir Manan, is not directly legally obligatory because it is not a statutory regulation, but it does include legal importance. [8]. The goal is for policy regulation to be directed primarily at the state administration agency or official. Therefore, the state administration agency is the first agency to implement the provisions contained in the policy regulations. However, these provisions will indirectly affect the general public. It can be concluded that the COVID-19 Task Force Circular is not a statutory regulation but a policy regulation issued from the principle of discretion. Furthermore, the COVID-19 Task Force Circular which suspended mudik activities from 6-17 May 2021 for all regions of Indonesia and urged all people to carry out virtual mudik during the period of suspending mudik were policies that were indirectly legally binding but contain legal relevance for the community.

\section{b) Law Enforcement Officers Factors}

What is meant by law enforcement officers in this study are those who were directly involved in law enforcement officers related to the implementation of the COVID-19 Task Force Circular Number 13 of 2021, in this case the police. A study conducted by Soerjono Soekanto concluded that in order to carry out law enforcement appropriately, the following factors must be properly implemented [9]:

1. Provision of examples of legal compliance by law enforcement officers;

2. The straightforward attitude of law enforcement officers;

3. Adjustment of applicable regulations with the latest technological developments;

4. Information and counseling regarding regulations that apply to the community; and

5. Provision of sufficient time for the community to understand the new regulations.

In order to carry out their roles well, law enforcement officers are required to be able to overcome obstacles that may be encountered, both from themselves and their environment. The obstacles that need to be overcome are [10]:

1. Restricted capacity to put one's own in the shoes of other person with whom one interacts;

2. Low level of aspiration;

3. Lack of enthusiasm for thinking about the future, making projections difficult;

4. The inability to postpone the satisfaction of a certain need, particularly material needs; and

5. lack of suitable innovation for conservatism.

The implementation of the COVID-19 Task Force Circular, the police, as part of law enforcement officers were required to set an example to the community and be straightforward in implementing the COVID-19 Task Force Circular, especially in responding to the suspension of mudik activities and virtual mudik implementation in order to prevent an increase in COVID-19 transmission during the holy month of Ramadan. and Eid al-Fitr in 1442 Hijri.

\section{c) Facilities and Infrastructures Factors}

In this research, "facilities" or "infrastructures" refers to human personnel who are educated and skilled, as well as excellent organization, suitable equipment, and sufficient funds. In suspending mudik activity, the government blocked several routes at 333 points. To implement this policy, government required an adequate number of police personnel, representative mudik isolation post facilities, health workers, and the department of 
transportation in field to assist the police. This activity would be effective if this policy can be implemented well for 24 hours so that people could not mudik and chose to do it virtually as the intention of the COVID-19 Task Force Circular Letter.

\section{d) Community Factors}

In this study, community factors were reviewed from awareness and compliance with established laws. The level of community compliance towards laws was based on the following factors [11]:

1. Knowledge of regulations;

2. Knowledge of the content of regulations;

3. Attitude towards regulations; and

4. Behavior in accordance with the rules.

Law in society can also be seen from the role of environmental factors in which the law applies. This provision explains about the role of informal institutions on the socialization agenda attended by community members, especially legal officials [12]. In the Covid-19 Task Force Circular, socialization of the suspension of mudik and efforts to control COVID-19 during the holy months of Ramadan and Eid al-Fitr in 1442 Hijri were carried out by all stakeholders, including but not limited to the community as follows:

a. Religious figures/leaders to their people and community leaders to the general public;

b. The head of the village to the residents of the origin area;

c. Business leaders or employers in the non-formal sector to their workers; and

d. Media to the general public.

From the description, socialization to the public regarding the COVID-19 Task Force Circular which suspended mudik from 6-17 May 2021 for all regions of Indonesia and urged all people to carry out virtual mudik was important for all stakeholders to do.

\section{e) Cultural Factors}

Cultural variables are defined in this study as values that underpin relevant laws as well as values that take the shape of abstract notions of what is deemed good and wrong. Mudik is a socio-cultural phenomenon. Various rational reasons seem unable to explain the phenomenon as it has been an Indonesian culture. Mudik for once a year is not just releasing the longing for home, but it has a much deeper feeling than that. There are indeed various reasons why people mudik during Eid al-Fitr. This phenomena, on the other hand, is obviously linked to cultural factors, which include the urge to see parents and relatives, perform pilgrimages to relatives' graves, and explore the family's heritage in the place of origin [13].

Eid al-Fitr is a day that is considered very sacred and important, especially for Muslims in Indonesia. On this holiday, people usually do not take into account the profit and loss, but a lasting annual happiness that is celebrated with family in their hometown. It can be said that mudik Indonesia people is an annual activity regardless of the community socio-economic status; therefore, mudik has become a top priority during Eid al-Fitr [14]. From the description, it can be concluded that mudik has become a culture for Indonesian people to celebrate Eid al-Fitr in their hometown. Eliminating mudik and calling for virtual mudik is something new for the community to do. 


\section{Conclusion}

On April 22, 2021 to May 14, 2021 (before and during Eid holidays), there were 3.9 million people mudik by public transportation modes (land, sea, and air). As a result, the community did not completely comply with the COVID-19 Task Force Circular, which halted mudik across Indonesia during the holy months of Ramadan and Eid al-Fitr in 1442 Hijri and asked everyone to undertake virtual mudik. The implementation of the COVID-19 Task Force Circular which suspended mudik from 6-17 May 2021 for all regions of Indonesia and urged all people to do virtual mudik during the period was influenced by the following factors:

a. The legal factors, namely the COVID-19 Task Force Circular Number 13 of 2021;

b. The law enforcement officers factors, namely the parties that formed and implemented the law;

c. Facilitates and infrastructures factors that supported law enforcement;

d. Community factors, namely the environment in which the law applied; and

e. Cultural factors in social life.

\section{Acknowledgement}

The author would like to thank all those who have provided constructive input so that this article can be completed. Hopefully this article can be useful theoretically and practically for the addition and development of legal knowledge, especially in legal awareness and legal compliance during the pandemic.

\section{References}

[1] Prasojo, A.P.S., Aini, Y.N., and Kusumaningrum, D.: Potensi Pola Aliran Mudik pada Masa Pandemi Covid-19. Jurnal Kependudukan Indonesia Edisi Khusus Demografi dan COVID-19. pp. 21-26 (2020)

[2] https://covid19.go.id/peta-sebaran

[3] https://www.ekon.go.id/publikasi/detail/3024/evaluasi-ppkm-mikro-kebijakanpeniadaan-mudik-dan-pengetatan-perjalanan-pemerintah-perpanjang-penerapannya

[4] Soekanto, S.: Faktor-faktor yang Mempengaruhi Penegakan Hukum. RajaGrafindo Persada. pp. 8 (2005)

[5] Sibuea, H.P.: Asas Negara Hukum, Peraturan Kebijakan, dan Asas-asas Umum Pemerintahan yang Baik. Erlangga. pp. 95 (2010)

[6] Ridwan, H.R.: Hukum Administrasi Negara. RajaGrafindo Persada. pp. 183 (2006)

[7] Hadjon, P.M., et al: Pengantar Hukum Administrasi Indonesia. Gadjah Mada University Pers. pp. 147 (2005)

[8] Sibuea, H.P.: Asas Negara Hukum, Peraturan Kebijakan, dan Asas-asas Umum Pemerintahan yang Baik. Erlangga. pp. 124 (2010)

[9] Fuadi, M.: Aliran Hukum Kritis Paradigma Ketidakberdayaan Hukum. Citra Aditya Bakti. pp. 46 (2003)

[10] Soekanto, S.: Faktor-faktor yang Mempengaruhi Penegakan Hukum. RajaGrafindo Persada. pp. 34-35 (2005)

[11] Soekanto, S.: Kesadaran Hukum dan Kepatuhan Hukum. Rajawali. pp. 272-273 (1977)

[12] Rahardjo, S.: Hukum dan Masyarakat. Angkasa. pp. 168 (1986) 
[13] Arribathi, A.H., and Aini, Q.: Mudik dalam Perspektif Budaya dan Agama. Journal CICES Vol. 4 No. 1 (2018)

[14] Soebyakto, B.B.: Mudik Lebaran. Jurnal Ekonomi Pembangunan. Pp 61-67 (2011) 